Article

\title{
The Relationship between Organizational Commitment and Organizational Citizenship Behaviors in the Public and Private Sectors
}

\author{
Dorota Grego-Planer ${ }^{D}$ \\ Faculty of Economic Sciences and Management, Nicolaus Copernicus University in Torun, ul. Gagarina 13A, \\ 87-100 Torun, Poland; dgp@umk.pl
}

Received: 30 September 2019; Accepted: 9 November 2019; Published: 14 November 2019

\begin{abstract}
Organizational Citizenship Behaviors (OCBs) are activities which are voluntary, go beyond the formal obligations of employees, and significantly affect the efficiency of the entire organization. The literature has devoted a lot of attention to them since the beginning of the 1980s. Not only has the nature of OCBs been studied, but so too have their dimensions and antecedents. However, there is a fairly significant research gap in the area of employee manifestations of citizenship behaviors according to type of organization (private and public sectors). This article addresses the issue of organizational commitment as one of the antecedents of OCBs. The research objective is to identify and assess the level of correlation between individual dimensions of organizational commitment and Organizational Citizenship Behaviors in public and private organizations in Poland. A quantitative study conducted on a sample of 323 employees allowed the hypotheses to be verified. In general, there are similar frequencies of Organizational Citizenship Behaviors in the public and private sectors. In public institutions, however, OCBs in the interpersonal dimension are more frequent, while in private institutions they occur more commonly in the organizational dimension. Most positively correlated with OCBs is the affective dimension of organizational commitment.
\end{abstract}

Keywords: organizational citizenship behavior; organizational commitment; affective commitment; normative commitment; continuance commitment; public and private sector

\section{Introduction}

The term 'Organizational Citizenship Behaviors' (OCBs) was coined in the 1980s. It means, employee behaviors that are not subject to a formal system of obligations but that have a positive impact on the functioning of the organization. An employee who feels that he/she is a 'citizen' of his/her organization, like a citizen of a state, voluntarily undertakes actions that benefit not only his/her colleagues, but also the organization as a whole. The essence of all these behaviors is that the person undertaking them does not expect his/her own benefits. In today's extremely fast-growing, but also very complex, organizations it is important that as many employees as possible exhibit behaviors that go beyond the formal scope of tasks. With such a competitive and global market, this can have a huge impact on the success of the organization.

The author of the concept of OCB, D.W. Organ, defines it as 'an individual behavior that is discretionary, not directly or explicitly recognized by the formal reward system, and that in the aggregate promotes the effective functioning of the organization' [1] (p. 4). OCBs are employee behaviors that are not part of an individual job description, are not included in an employee contract, and are beneficial to organizational performance. Employees conduct them without expecting rewards, motivated by willingness to support their workmates and the organization [2-6]. The subject literature 
lists seven main categories of citizenship behaviors: helping behavior, sportsmanship, organizational loyalty, organizational compliance, individual initiative, civic virtue, and self-development [5].

The occurrence of citizenship behaviors itself can be considered in two dimensions-frequency and intensity. The frequency dimension is related to how many employees exhibit these behaviors and how often. Intensity is considered through the qualitative dimension, i.e., the degree of employee commitment in OCB and the type of these behaviors [7]. Numerous authors cite various factors, as well as whole groups of factors, that may affect the manifestation of citizenship behaviors in the organization. Spector and Che divided the factors into six groups: attitude (e.g., commitment, level of job satisfaction), negative and positive emotions experienced in connection with the work performed, personality (e.g., diligence), the so-called stressors (e.g., conflicts and their role), employee relations with the supervisor, and the perception of procedures [8]. Other authors point to, for example, leadership behavior, loyalty to the leader, authentic leadership, organizational culture, organizational relations, or organizational justice [9-12]. Therefore, organizational and citizenship behaviors will be influenced by both organizational and leadership factors, as well as those related to employees themselves.

The scientific world has also devoted much attention to OCB antecedents. It is said that these behaviors are closely related to job attitudes (job satisfaction, perception of fairness and organizational commitment), task variables and leadership behaviors. The subject of the research that this article reports on includes employees' attitude of organizational commitment as a prerequisite for OCB. Organizational commitment is understood as employee identification with the organization [13]. Lambert [14] and Steers [15] defined organizational commitment as the individual's strength with and involvement in the organization. Organizational commitment can occur in three dimensions: affective commitment, normative commitment, and continuance commitment [13]. Affective commitment is defined as "the strength of an individual's identification with and involvement in a particular organization" [16] (p. 604). Normative commitment reflects the sense of obligation to continue in employment. Employees with a high level of normative commitment feel that they ought to remain with the organization [17]. The last dimension-continuance commitment-represents cognitive attachment between employees and their organizations because the costs of leaving outweigh the benefits [18].

The research objective of this article is to determine and evaluate the level of correlation between the various dimensions of organizational commitment and Organizational Citizenship Behaviors in public and private organizations in Poland. The author intentionally focused on these two types of organizations, since the research on OCB rarely addresses the impact of the type of organization on the manifestation of citizenship behaviors. Therefore, this work is an attempt to fill part of the existing research gap in the studied area.

\section{Theoretical Background and Hypotheses}

\subsection{Organizational Citizenship Behavior}

OCB typically refers to behaviors that positively impact the organization or its members. The concept of OCB regards employee behaviors that are not part of an individual job description, are not included in an employee contract, and are beneficial to organizational performance [2,3]. OCBs are voluntary behaviors of organization members; they go beyond the scope of their job responsibilities, and are aimed at assisting co-workers and/or taking care of the organization and its operations. S.P. Robbins claims that OCBs are staff behaviors that are not part of their required work, but support the effective functioning of the organization [19]. Podsakoff et al. define organizational citizenship behaviors as behaviors that do not appear in the formal job description, but facilitate the performance of tasks in the organization [20].

Such behaviors include: helping a new employee to catch up, helping a co-worker to deal with work overload, staying at work after hours, taking on additional responsibilities, tolerating temporary 
impositions without complaint, defending an organization, openly speaking about issues of importance to the organization, etc. [5,21].

As highlighted in the literature, OCB may be directed towards the organization (e.g., carrying out role requirements well beyond minimum required levels) and/or towards individual co-workers (e.g., helping a particular other person with a relevant task) and may contribute only indirectly to the organization $[5,6,22]$.

Several studies in the organizational literature highlight the benefits of OCBs. Among others, it has been found that employee engagement in OCBs may increase knowledge sharing and job performance $[23,24]$. Other authors claim that OCBs exhibited by workers enhance team and group cohesiveness and contribute to overall organizational performance [2,23,25-27]. At the same time, OCB does not mean working long hours and taking on extra assignments with no thought of reward. Rather, it means that, through this type of behavior, employees provide the organization with many creative solutions to problems and provide suggestions to facilitate the implementation of strategies [28].

Initially, researchers described various OCBs in terms of two factors: altruism and serving principles. Altruism defined behaviors aimed at helping other colleagues, while the other factor was related to maintaining rules and norms for cooperation and supporting team spirit. Over time, many researchers began to add in more groups of voluntary behaviors that go beyond formal responsibilities while affecting organizational effectiveness.

As a result, Podsakoff and his colleagues attempted to systematize the subject literature. Based on a review of previous publications, they identified almost 30 theoretical constructs to describe activities that can be classified as various forms of OCB. Nevertheless, these behaviors overlapped in many ways. Their comparison helped distinguish seven main categories of citizenship behaviors: helping behavior (including altruism and courtesy), sportsmanship, organizational loyalty, organizational compliance, individual initiative, civic virtue, and self-development [20].

In their conceptual framework Podsakoff et al. claim that helping behavior refers to voluntarily helping others with, or preventing the occurrence of, work-related problems [20]. The first part of the above definition refers to helping others with work-related problems. This includes several elements highlighted by different researchers, such as altruism or peace-making $[1,29,30]$. Altruism is directly intended to help a specific person in face-to-face situations (e.g., helping others who have been absent, volunteering for things that are not required, orienting new people even though it is not required, helping others who have heavy workloads). Peace-making refers to behaviors aimed at preventing or solving conflicts and cheerleading [1,31].

The second OCB dimension is sportsmanship. This dimension is explained as a citizen-like posture of uncomplainingly tolerating the inevitable inconveniences and impositions of work $[1,20]$.

The third dimension of OCBs is organizational loyalty. Organizational loyalty entails promoting the organization to outsiders, protecting and defending it against external threats, and remaining committed to it even under adverse conditions [20,32]. The next dimension, organizational compliance, refers to internalization and employee's acceptance of and strict adherence to organizational procedures and policies. In more practical terms it means that an employee obeys organizational norms even if nobody can see it $[4,20]$.

Individual initiative, the next OCB dimension refers to going well beyond minimally required levels of effort. Such behaviors include voluntary acts of creativity and innovation designed to improve one's task or the organization's performance, persisting with extra enthusiasm and effort to accomplish one's job, volunteering to take on extra responsibilities, and encouraging others in the organization to do the same. Examples of such behavior are proposing improvements to the organization, voluntarily engaging in additional responsibilities, punctuality, and housekeeping. [1,4,20,32].

The next dimension of OCBs proposed by Podsakoff et al. is civic virtue [20]. This concerns an employee's willingness to participate in the governance process and to take responsibility for the whole organization. In practice, civic virtue includes responsible, constructive involvement in the political process of the organization, attending the organization's meetings, voluntarily monitoring 
the organizational environment to identify potential threats and opportunities, and voluntary acts of creativity and innovation in organizations. [4,20,29,33].

The last of the seven OCB dimensions proposed by Podsakoff et al. is self-development. This dimension includes voluntary behaviors that employees engage in to improve their knowledge, skills, and abilities to then be able to better contribute to the organization $[6,20,33]$.

In addition to the above-mentioned division of OCB into seven categories, the literature also proposes the typology of Williams and Anderson, who divide these behaviors into those that are people-oriented (OCB-P) and organization-oriented (OCB-O). OCB-P is understood as behaviors that by helping a particular person (e.g., showing compassion toward colleagues experiencing personal problems) contribute to the more effective operation of the company. They are therefore closely related to altruism. OCB-O, in turn, refers to the activities of an employee that support the organization as a whole. They are manifested, for example, in compliance with formal and informal rules in force in the company, which help avoid problems in its functioning [34]. As Spitzmuller claims, the dividing OCBs according to the target of the behavior is extremely important for researchers and theorists because of the distinctness of the nomological networks of the two forms of OCB [35].

Yet another classification is proposed by Van Dyne, Cummings, and Parks, who distinguish between affiliation-oriented (AOCB) and challenge-oriented citizenship behavior (COCB). The former is focused on permanent support by maintaining the existing relationships and processes in the organization. The latter is related to actions leading to changes in the organization by improving current relationships and processes [36].

The specifics of how an organization works, co-worker relations, forms and levels of employee remuneration and many other factors can influence what kind of organizational citizenship behaviors (OCB-P and OCB-O) employees manifest. Based on the review of the subject literature and due to the differences in how the surveyed organizations function, I postulate the following hypotheses:

Hypothesis 1. The frequency at which organizational citizenship behaviors manifest is similar in the public and private sectors.

Hypothesis 2. Public-sector employees manifest more people-oriented than organization-oriented citizenship behaviors.

\subsubsection{OCB: Effects}

Regardless of the variety of definitions and classifications of organizational citizenship behaviors, all researchers agree that they are a heterogeneous construct and consist of many dimensions covering different categories of behavior. The concept of OCB is derived from the premises of the theory of interpersonal relations, in which the organization is treated as 'a kind of social system-a form of social organization in which certain informal norms and rules of coexistence apply. They exist outside official procedures, creating communities governed by specific, developed values, distinguished by established principles of cooperation, atmosphere, etc.' [37] (p. 31). Therefore, organizational citizenship behaviors falling into this category serve as an example of a positive system that favors the development of an organization. Despite the fact that OCBs are by definition voluntary, uncontrolled behavior, their consequences are visible in the results of the organization's operation. OCBs can also affect the effectiveness of an organization by:

- $\quad$ reducing disparities in the level of tasks performed and results achieved [26];

- $\quad$ increasing the productivity of colleagues and superiors [38,39];

- $\quad$ freeing up resources for more productive purposes [3];

- $\quad$ enhancing the organization's ability to attract and retain the best employees $[1,40]$.

At this point the ever-strengthening relationship between OCB and corporate social responsibility (CSR) also needs to be emphasized. CSR can be defined as "the strategies and actions that 
primarily deal with organizations' or firms' voluntary relationships with their community and societal stakeholders" [41]. Until recently, researchers into CSR had mainly focused on external stakeholders, such as investors and customers [42,43]. Now, attention has shifted decidedly onto employees $[12,44,45]$. Employees are one of the most important stakeholders in any organization. Since they both affect and are affected by organizational activities, employees play a key role in the success or failure of their organization.

Global empirical research has confirmed the significant positive impact of CSR on employee attitudes and behavior [46,47]. This relationship is also inverse. Researchers are increasingly focusing on individual-level CSR perspectives, suggesting that employee attitudes and behavior play a key role in transforming CSR into beneficial organizational outcomes. When an organization begins doing various types of activity for the welfare of its employees, employees also respond by demonstrating better citizenship behaviors in the workplace and a positive attitude towards their organization. According to Social Exchange Theory, when an employee develops a psychological relationship with the organization, he engages more in his professional and organizational role. Saks [48] noted a significant positive relationship between employee engagement and job satisfaction, organizational commitment, and organizational citizenship behavior, as well as a significant negative relationship with intention to quit. An organization implementing CSR can increase employees' sense of their own importance at work; employees feel that they are part of an organization that is serving the community to make the world a better place. Albdour and Altarawneh [49] observed a significant positive relationship between employees' perception of an internally focused CSR and their organizational commitment.

For this reason, CSR should be treated as a long-term investment that supports sustainable company development [50]. Furthermore, companies with better social performance are more likely to have positive earnings [51]. Organizations should therefore take actions that support employees' engagement and their exhibiting of OCBs, as well as motivating their CEO to take risks with regard to CSR. The author may tackle these relationships as the subject of another future study.

Due to the impact of citizenship behaviors on the effectiveness of organizations that has already been confirmed by numerous studies, they are interested in making this phenomenon universal and frequent. For the organization, not only the frequency, but also the intensity of these behaviors (the degree of employee involvement in OCB and the type of behavior) matters.

\subsubsection{OCB: Antecedents}

Many antecedents have been studied in relation to OCB. Many researchers point to the following four key categories of OCB antecedent: individual (employee) characteristics, task characteristics, organizational characteristics, and leadership behaviors [20,52]. Previous studies have shown that OCB is strongly correlated with job attitudes, task variables, and leadership behaviors. In the first category, job satisfaction, perception of fairness and organizational commitment in particular make employees want to engage in citizenship behavior. When considering the features of tasks, researchers unanimously emphasize their strong relationship with the manifestation of OCB. It is important that the task be intrinsically satisfying and accompanied by feedback. The most important leadership behaviors from the OCB point of view are supportive leader behaviors, transformational leadership, and the leader-follower exchange [31].

In this research, the author wanted to confirm the previously examined relationship between organizational involvement and $\mathrm{OCB}$, but taking into account the aspect of two different types of organizations I assume that:

Hypothesis 3. There is a positive relationship between the attitude of organizational commitment and organizational citizenship behaviors of employees in both public and private institutions.

Due to the subject matter of the article, organizational commitment will be described from here on with particular emphasis on its impact on manifesting organizational citizenship behaviors. 


\subsection{Organizational Commitment and $O C B$}

Organizational commitment $(\mathrm{OC})$ is defined as 'the relative strength of an individual's identification with and involvement in a particular organization' [53] (p. 226). Colloquially, it can be considered that commitment is the same as the employee's membership of the organization. Organizational commitment exemplifies an employee's relationship with the organization. It is a 'mental state which has repercussion on the employee's choice whether to or not to maintain his membership in the organization' [54] (p. 26). To feel greater organizational commitment, employees must accept and sincerely believe in the company's values, make efforts to serve it, and enjoy being a member of it [55].

One of the most popular models of commitment to the organization is the Meyer and Allen model [13]. These authors treat organizational commitment as employee identification with the organization. Accordingly, Allen and Meyer theorize that organizational commitment encompasses three dimensions: affective commitment, normative commitment, and continuance commitment [13].

In its affective sense, commitment means the employee's emotional attachment to the organization, which reflects the degree to which the individual wants to be part of the organization. The employee wants to be identified with the organization and also to get involved in its affairs. Persons with strong affective commitment work in the organization of their own free will, not by coercion [56]. The affective dimension is closely linked to the positive feelings associated with the place of employment (a sense that work allows them to meet needs and goals, satisfaction, and a feeling of support from superiors and the entire organization) [57]. Affective commitment (AC) is determined by 'an employee's personal choice to remain committed to the organization via some emotional identification with the organization' [58] (p. 86). Affective commitment is a positive attitude toward the organization [59]. Mahal [60] additionally points out that the employee's attitude as an individual is related to personal values which that person brings to the organization. As M. Łaguna, E. Mielniczuk, and E. Wuszt claim, 'people with strong affective commitment work more and achieve better results than those who do not display this type of attachment' [61] (p. 50). The Meyer and Allen model illustrates that affective commitment can be influenced by several factors such as direct clarity of goals and a degree of manageable difficulty in reaching goals, job challenges, management receptiveness to feedback, role clarity provided by the organization, peer cohesion, equity of opportunity and compensation, perceived personal importance, and timely and constructive feedback [13].

Continuance commitment (CC) is associated with cost calculation in the event of leaving the organization [13]. An employee who exhibits this dimension of commitment remains in the organization, because he/she perceives it as a kind of compulsion, and believes that he/she must do so. It develops when the costs of leaving are too high, when an employee has made too much investment in a given organization or when he/she does not see any alternative employment [57]. Continuance commitment can be regarded as a contractual attachment to the organization [62]. The person's attachment to the organization in this dimension is constantly based on the assessment of the economic benefits obtained by staying in it [63]. An employee who displays continuance commitment performs his/her duties worse and has more difficult relationships with colleagues.

The third and last dimension of organizational commitment proposed by Meyer and Allen is normative commitment (NC). It is associated with a sense of moral obligation to remain in the organization. At the core of manifestation of normative commitment are socialization experiences gained at first in the family and later in the workplace, especially if the importance of loyalty to one organization was emphasized [13]. The NC level may be influenced by the rules an individual accepts and the reciprocal relationship between an organization and its employees [64].

Researchers into organizational commitment very often determine the dependence between its individual dimensions and the organizational behavior an employee displays. Empirically confirmed research indicates that employees with highly developed affective commitment are more valuable to organizations than those with lower levels. Similar but weaker effects are observed when normative commitment is manifested. The worst results are observed in the case of employees with strong continuance commitment. Numerous studies also indicate that there are negative correlations between 
organizational commitment and the tendency to leave the organization and staff turnover. This relationship is strongest in affective commitment, but it applies to all of the three dimensions $[65,66]$. Mathieu and Zajac [67] also recognized the dependence between organizational commitment and employee absenteeism. It is characteristic of the affective dimension, but it does not occur in the case of continuance commitment. Affective commitment has also been the most consistent and strongest predictor of positive organizational outcomes, such as work effort and performance [59,68].

The subject literature clearly indicates the correlations between organizational commitment and Organizational Citizenship Behavior (this is discussed in the 'OCB: antecedents' section). Studies confirm that this affective nature of organizational commitment is most correlated with OCB [20] but it is important to 'take into account the other forms of commitment that can be present at the same time for the same individual' [52] (p. 53).

Based on previous related empirical findings, I postulate the following hypotheses:

Hypothesis 4. The dimension most positively correlated with OCB is the affective dimension of organizational commitment of employees both in public and private institutions.

\section{Hypothesis 5. Continuance commitment is uncorrelated with OCB in both types of organizations.}

The purpose of this publication is to identify and assess the level of correlation between the various dimensions of organizational commitment and Organizational Citizenship Behavior in public and private organizations in Poland. The author first presents the frequency of OCB manifested by employees of individual institutions, and then seeks to find whether there are differences in the level of organizational commitment of these employees taking into account their workplace. Then, the correlations between CC and OCB will be presented.

\section{Method}

\subsection{Sample and Procedures}

Figure 1 shows the conceptual framework of the study, which portrays the impact of individual dimensions of organizational commitment on Organizational Citizenship Behavior in public and private institutions.

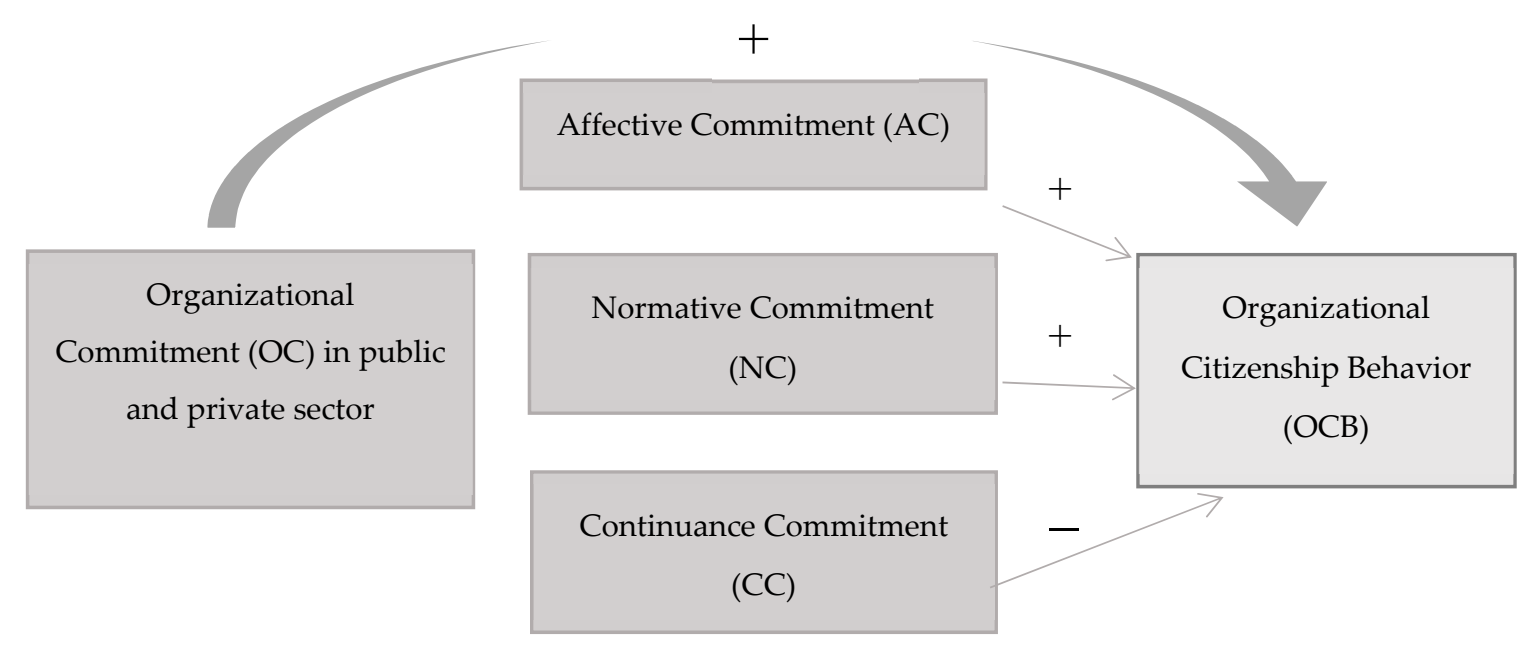

Figure 1. Conceptual framework.

The author's own research was conducted between October 2018 and February 2019. Data were collected from various institutions. Most of them were public and private schools. The directors of all organizations granted their permission to carry out the study, and respondents were assured 
of the confidentiality of their responses. The survey involved 323 employees of public and private institutions in Poland. Over 50\% of them were respondents from public institutions, and the rest from private. The structure of the research sample is shown in Table 1.

Table 1. Research sample.

\begin{tabular}{cccc}
\hline & Total per category & $\begin{array}{c}\text { Number of } \\
\text { Respondents }\end{array}$ & $\begin{array}{c}\text { Percentage of } \\
\text { Respondents } \%\end{array}$ \\
\hline Category & Women & 323 & 100.0 \\
\hline \multirow{2}{*}{ Gender } & Men & 272 & 84.2 \\
& $18-25$ & 51 & 15.8 \\
\hline \multirow{2}{*}{ Age } & $26-35$ & 15 & 4.6 \\
& $36-45$ & 44 & 13.7 \\
& 4655 & 119 & 36.8 \\
\multirow{2}{*}{ Education } & Vocational & 145 & 44.9 \\
& Secondary & 0 & 0 \\
& Higher & 27 & 8.3 \\
\multirow{2}{*}{ Type of employment } & During studies & 290 & 89.8 \\
& Contract & 6 & 1.9 \\
\hline \multirow{2}{*}{ Working hours } & Civil law contract & 279 & 86.4 \\
& Full-time job & 44 & 13.6 \\
\hline \multirow{2}{*}{ Workplace } & Part-time job & 274 & 84.8 \\
& Public institution & 49 & 15.2 \\
\hline
\end{tabular}

The vast majority of respondents were women. They constituted over $84 \%$ of respondents. A large proportion of the respondents were people aged 36-45 (36.8\%) and 46-55 (44.9\%). Almost $90 \%$ of respondents have a higher education. The vast majority are employed under a full-time employment contract.

\subsection{Measurements}

In order to verify the hypotheses, a quantitative study was carried out using a structured questionnaire. In our study we applied the Citizenship Behavior Scale of Fox and Spector, that is, the Organizational Citizenship Behavior Checklist [69]. This includes 20 items describing activities both aimed at helping co-workers and at the same time beneficial to the organization. The sum of these activities indicates the general level of OCB undertaken by the employee [69]. Using the five-point Likert frequency ratio, an investigated employee estimated how often in his/her current work he/she undertook the indicated activities, where 1 meant never, 2-once or twice, 3-once or twice a month, 4 -once or twice a week, and 5-every day.

The scale proposed by Meyer and Allen is most often used when studying organizational commitment [13]. These authors constructed the scale of organizational commitment based on their proposed three-component model of commitment to the organization. The questionnaire consists of three subscales measuring the affective, continuance, and normative dimensions of commitment. The individual statements in the questionnaire concern feelings and beliefs describing the employee's relationships with the organization. The scale of affective commitment contains statements regarding the employee's emotional involvement in the organization (expresses his/her personal ties). The scale of continuance commitment is made up of content related to the employee's perception of the costs of leaving the organization and the lack of alternative employment opportunities. The scale of normative commitment, in turn, relates to the sense of moral obligation to remain in the organization, based on employee loyalty [13]. 
In this study, a Polish version of the Meyer and Allen Scale was used, whose validity and reliability have been thoroughly tested by A. Bańka, A. Wołoska and R. Bazińska [70]. Respondents expressed their opinion on 18 statements (continuance commitment-six items, normative commitment—six items, and affective commitment-six items) on a scale of 1 to 5 , where 1 meant totally disagree and 5 totally agree.

\section{Results}

The research was primarily intended to show the frequency of display of organizational citizenship behaviors in public and private organizations.

In order to check whether the structure of responses to the questions varied depending on the type of organization in which the respondents worked, the Kolmogorov-Smirnov $\alpha$ compliance test was applied with a significance level of 0.05 . The results are presented in Table 2.

Table 2. The structure of answers—statistical value $\lambda$.

\begin{tabular}{|c|c|}
\hline Item & Statistical Value $\lambda$ \\
\hline 1. Picked up meal for others at work & 0.682 \\
\hline 2. Took time to advise, coach, or mentor a co-worker. & 1.953 \\
\hline 3. Helped co-worker learn new skills or shared job knowledge. & 0.534 \\
\hline 4. Helped new employees get oriented to the job. & 0.527 \\
\hline 5. Lent a compassionate ear when someone had a work problem. & 0.959 \\
\hline 6. Lent a compassionate ear when someone had a personal problem. & 1.069 \\
\hline 7. Changed vacation schedule, work days, or shifts to accommodate co-worker's needs. & 0.194 \\
\hline 8. Offered suggestions to improve how work is done. & 0.132 \\
\hline 9. Offered suggestions for improving the work environment. & 0.424 \\
\hline 10. Finished something for co-worker who had to leave early. & 0.493 \\
\hline 11. Helped a less capable co-worker lift a heavy box or other object. & 0.999 \\
\hline 12. Helped a co-worker who had too much to do. & 1.764 \\
\hline 13. Volunteered for extra work assignments. & 0.531 \\
\hline 14. Took phone messages for absent or busy co-worker. & 1.360 \\
\hline 15. Said good things about your employer in front of others. & 1.069 \\
\hline 16. Gave up meal and other breaks to complete work. & 1.601 \\
\hline $\begin{array}{l}\text { 17. Volunteered to help a co-worker deal with a difficult customer, vendor, or } \\
\text { co-worker. }\end{array}$ & 0.845 \\
\hline 18. Went out of the way to give co-worker encouragement or express appreciation. & 0.745 \\
\hline 19. Decorated, straightened up, or otherwise beautified common work space. & 0.091 \\
\hline $\begin{array}{l}\text { 20. Defended a co-worker who was being 'put-down' or spoken ill of by other } \\
\text { co-workers or supervisor. }\end{array}$ & 1.655 \\
\hline Critical value & $\lambda=1.36$ \\
\hline
\end{tabular}

Table 3 presents descriptive statistics on the frequency of organizational behaviors in the public and private sectors, also dividing these behaviors into the interpersonal and organizational dimensions.

The data contained in Table 2 showed that only in five questions were differences in the structure of answers statistically significant. In addition, the weighted mean of all responses is 2.54 and 2.42, respectively (Table 3). These results confirm Hypothesis 1, that:

The frequency at which organizational citizenship behaviors manifest is similar in the public and private sectors. 
Behaviors exhibited by employees of public institutions are more likely to be directed at colleagues than at the organization (Table 3). These results therefore confirm Hypothesis 2, that:

Public-sector employees manifest more people-oriented than organization-oriented citizenship behaviors.

Table 3. Descriptive statistics of Organizational Citizenship Behavior (OCB) in the public and private sectors.

\begin{tabular}{cccc}
\hline & Mean & Me & Mo \\
\hline OCB & $\mathbf{2 . 4 9}$ & 2 & 2 \\
\hline Public Sector & 2.54 & 2 & 2 \\
\hline Private Sector & 2.42 & 2 & 2 \\
\hline OCB-0 & & & 2 \\
\hline Public Sector & 2.27 & 2 & 2 \\
\hline Private Sector & 2.35 & 2 & 2 \\
\hline OCB-P & & & 2 \\
\hline Public Sector & 2.52 & 2 & \\
\hline Private Sector & 2.25 & 2 & \\
\hline
\end{tabular}

Note: OCB-O-behaviors directed toward the organization; OCB-P-behaviors directed toward people in the organization; Me-median; Mo-mode.

The next part of the research involved determining respondents' level of organizational commitment. Table 4 shows the weighted mean, standard deviation, minimum and maximum levels, and scopes of organizational commitment (affective commitment, continuance commitment, and normative commitment) of the employees surveyed.

Table 4. Descriptive statistics on organizational commitment and its sub-scales.

\begin{tabular}{ccccccc}
\hline Organizational Commitment & $\mathbf{n}$ & Min. & Max. & Mean & SD \\
\hline $\begin{array}{c}\text { Variables of } \\
\text { organizational } \\
\text { commitment }\end{array}$ & $\begin{array}{c}\text { Affective } \\
\text { commitment }\end{array}$ & 323 & 2.67 & 4.83 & 4.5 & 0.55 \\
\cline { 2 - 6 } & $\begin{array}{c}\text { Continuance } \\
\text { commitment }\end{array}$ & 323 & 2.17 & 4.83 & 4.12 & 0.77 \\
\hline $\begin{array}{c}\text { Normative } \\
\text { commitment }\end{array}$ & 323 & 2.17 & 4.67 & 4.13 & 0.74 \\
\hline $\begin{array}{c}\text { Perception of organizational } \\
\text { commitment }\end{array}$ & 323 & 2.34 & 4.78 & 4.25 & 0.69 \\
\hline
\end{tabular}

The results indicate that the mean values of organizational commitment and its subscales are fairly high and reached values ranging from about 4.10 to 4.50 . Affective commitment obtained the highest mean. It is also worth looking at the results in individual types of organizations, as shown in Table 5.

Table 5. Organizational commitment and its dimensions in public and private institutions.

\begin{tabular}{ccccc}
\hline \multirow{2}{*}{ Type of Institution } & \multicolumn{4}{c}{ Mean } \\
\cline { 2 - 5 } & $\begin{array}{c}\text { Affective } \\
\text { Commitment }\end{array}$ & $\begin{array}{c}\text { Continuance } \\
\text { Commitment }\end{array}$ & $\begin{array}{c}\text { Normative } \\
\text { Commitment }\end{array}$ & $\begin{array}{c}\text { Organizational } \\
\text { Commitment }\end{array}$ \\
\hline Public $(\mathrm{n}=174)$ & 4.58 & 4.13 & 4.21 & 4.31 \\
\hline Private $(\mathrm{n}=149)$ & 4.40 & 4.11 & 4.04 & 4.19 \\
\hline
\end{tabular}


The data presented in Table 5 show that the level of organizational commitment is slightly higher for employees of the public institutions surveyed than for employees in the private sector. However, this difference is not very significant. In both organization types, the highest level was achieved by affective commitment, which certainly shows employees in a positive light.

The next part of the presented results strictly covers the main objective of the work, which was to determine and assess the correlation between individual dimensions of organizational commitment and Organizational Citizenship Behavior in public and private organizations in Poland, as well as analysis of the subsequent hypotheses.

Calculations were made using the IBM SPSS 24.0 software. In order to select appropriate statistical methods, the distributions' compliance with the normal distribution was assessed using the Kolmogorov-Smirnov test (Table 6). All analyzed variables showed distributions deviating from the normal distribution.

Table 6. Assessment of compliance of distributions with the normal distribution: the Kolmogorov-Smirnov test results carried out for one sample.

\begin{tabular}{cccccc}
\hline & $\mathbf{n}$ & \multicolumn{2}{c}{ Normal Distribution Parameters } & \multirow{2}{*}{$p$} \\
\cline { 3 - 5 } & & Mean & SD & Test Statistics & 0.000 \\
\hline OCB: mean & 323 & 2.487 & 0.1947 & 0.086 & 0.000 \\
\hline $\begin{array}{c}\text { Affective } \\
\text { commitment: mean }\end{array}$ & 323 & 4.496 & 0.3769 & 0.290 & 0.000 \\
\hline $\begin{array}{c}\text { Continuance } \\
\text { commitment: mean }\end{array}$ & 323 & 4.119 & 0.3377 & 0.133 & 0.000 \\
\hline $\begin{array}{c}\text { Normative } \\
\text { commitment: mean }\end{array}$ & 323 & 4.131 & 0.3259 & 0.242 & \\
\hline
\end{tabular}

Note: SD—standard deviation.

Non-parametric methods (Spearman's Rho correlation coefficients) were selected for further analysis. In addition, scatter point charts were used with a simple linear regression method along with the function formula ( $p<0.05$ was used as the statistical significance limit).

First, the relationship between the organizational commitment attitude and citizenship behavior of employees was examined among employees of public and private institutions. Data are presented in Table 7.

Table 7. Correlations between organizational commitment and OCB in public and private institutions.

\begin{tabular}{ccccc}
\hline & & Units & & OCB Mean \\
\hline \multirow{4}{*}{ Spearman's Rho } & \multirow{2}{*}{ Public } & Commitment: & Correlation coefficient & 0.489 \\
& & mean & $p$ & 0.000 \\
& & & $n$ & 174 \\
\cline { 2 - 5 } & \multirow{2}{*}{ Private } & Commitment: & Correlation coefficient & 0.527 \\
& & mean & $p$ & 0.000 \\
& & & $\mathrm{n}$ & 149 \\
\hline
\end{tabular}

A statistically significant positive relationship was found between OCB and organizational commitment. The research results confirm the hypothesis that there is a positive relationship between the attitude of organizational commitment and citizenship behaviors of employees in both public and private institutions.

The next step was to examine the correlation between the various dimensions of organizational commitment and OCB in both types of institutions. Data are presented in Table 8. 
Table 8. Dependence between the dimensions of organizational commitment and OCB in public and private institutions.

\begin{tabular}{|c|c|c|c|c|c|}
\hline \multicolumn{2}{|c|}{ Public Institution } & \multirow{2}{*}{$\begin{array}{c}\text { OCB: mean } \\
0.702\end{array}$} & \multicolumn{2}{|c|}{ Private Institution } & \multirow{2}{*}{$\begin{array}{c}\text { OCB: mean } \\
0.656\end{array}$} \\
\hline $\begin{array}{l}\text { Affective } \\
\text { commitment }\end{array}$ & $\begin{array}{l}\text { Spearman } \\
\text { Correlation }\end{array}$ & & $\begin{array}{c}\text { Affective } \\
\text { commitment }\end{array}$ & $\begin{array}{l}\text { Spearman } \\
\text { Correlation }\end{array}$ & \\
\hline mean & $p$ & 0.000 & mean & $p$ & 0.000 \\
\hline & $\mathrm{n}$ & 174 & & $\mathrm{n}$ & 149 \\
\hline \multirow{3}{*}{$\begin{array}{c}\text { Continuance } \\
\text { commitment: } \\
\text { mean }\end{array}$} & $\begin{array}{l}\text { Spearman } \\
\text { Correlation }\end{array}$ & 0.069 & \multirow{3}{*}{$\begin{array}{c}\text { Continuance } \\
\text { commitment: } \\
\text { mean }\end{array}$} & $\begin{array}{l}\text { Spearman } \\
\text { Correlation }\end{array}$ & 0.069 \\
\hline & $p$ & 0.364 & & $p$ & 0.402 \\
\hline & $\mathrm{n}$ & 174 & & $\mathrm{n}$ & 149 \\
\hline \multirow{4}{*}{$\begin{array}{c}\text { Normative } \\
\text { commitment: } \\
\text { mean }\end{array}$} & Spearman & 0.399 & \multirow{4}{*}{$\begin{array}{c}\text { Normative } \\
\text { commitment: } \\
\text { mean }\end{array}$} & Spearman & 0.452 \\
\hline & Correlation & לנט.0 & & Correlation & 0.000 \\
\hline & $p$ & 0.000 & & $p$ & \multirow{2}{*}{149} \\
\hline & $\mathrm{n}$ & 174 & & $\mathrm{n}$ & \\
\hline
\end{tabular}

A statistically significant positive relationship was demonstrated between organizational citizenship behaviors and affective and normative commitment in both the public and private groups. Organizational citizenship behaviors are most positively correlated with affective engagement (Figure 2). Less so, but also positively, they are correlated with normative commitment. However, they are not correlated with continuance commitment.

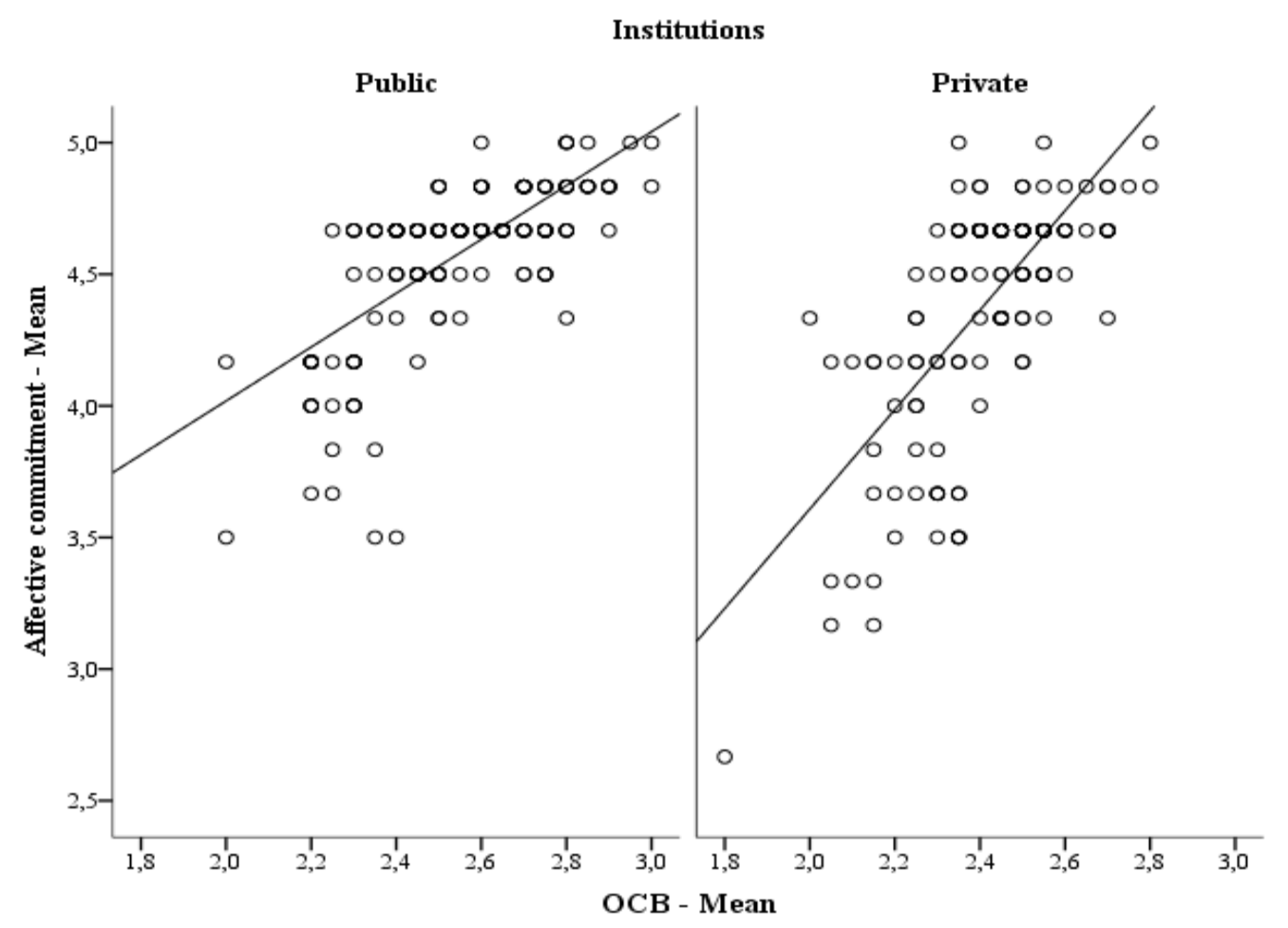

Figure 2. Scatter chart with linear regression line plotted.

Chart 2 confirms that there is a significant positive relationship between affective commitment and OCB in both groups, and therefore the increase in the value of the affective commitment is accompanied by an increase in the value of the OCB variable. 


\section{Discussion}

The major research objective of this publication was to identify and assess the level of correlation between the various dimensions of organizational commitment and Organizational Citizenship Behavior in public and private organizations in Poland. To achieve this objective, the author had to first verify the level of OCB and the level of organizational commitment among the respondents.

The results showed a very interesting but complex picture of $O C B$ in the organizations studied. The level of manifestation of this type of behavior in both public and private institutions is relatively similar. The weighted means of all responses are 2.54 and 2.42, respectively.

As Table 2 shows, the difference in the structure of answers to only five questions was statistically significant. In these questions, employees of public institutions more often marked four or five, which meant that the behavior was undertaken once or twice a week, or every day, respectively. The most noticeable differences were observed with regard to such aspects as taking time to advise, train or mentor a colleague. As many as $62 \%$ of the surveyed employees of public institutions indicated that they undertake this type of activity every day or several times a week.

Another frequency was also observed in the manifestation of citizenship behavior consisting in listening to the personal problems of their colleagues-here as many as $67 \%$ of public sector employees admitted that they do it once or twice a week, or every day. In the private sector, this figure was $45 \%$. Respondents from public institutions more often helped a colleague who had too much work on a given day, answered the phone for an employee who was busy and defended colleagues humiliated by the employer than those from private institutions. All of these behaviors are co-worker-oriented, rather than organization-oriented.

The results of the study also highlighted the fact that in both groups everyday OCB acts are quite rare. Both the median and mode of all aspects addressed in the OCB are two (where two on the OCB scale meant that the behavior had taken place only two or three times). In addition, a large proportion of respondents did not exhibit this type of behavior at all.

Focusing on the very organizational commitment, the results are truly surprising. The level of commitment of respondents can be described as high in both groups of respondents. Organizational commitment in the examined public institutions achieved an average result of 4.31, while in private ones it amounted to 4.19. High staff commitment can make any organization successful. Research by Towers Perrin-ISR performed already in 2006 showed that companies with high employee commitment reported a $13.2 \%$ increase in net income, while at the same time companies with a low level of commitment saw a decrease of $3.8 \%$ [71].

When analyzing various research results, M. Juchnowicz stated that committed employees are five times less likely to have accidents at work and lose seven times less time to hazardous events than employees who are not committed. Organizations with a higher level of employee commitment achieve $17 \%$ higher productivity and profits than competitors [72]. Therefore, such high levels of organizational commitment of the surveyed employees may constitute a very good position of their jobs. A definite surprise is the average result of affective commitment at 4.58 among public sector employees. After all, this dimension of commitment is most desired by employers. Affective commitment results from internal beliefs, often from passion or satisfaction. However, such a high result may result from the fact that a very large proportion of the respondents were school employees, who mostly see the teaching profession as their calling.

Analyzing the further results obtained, the focus was on the correlation between employee commitment and the manifestation of organizational citizenship behavior. An attempt was made to assess the level of correlation between individual dimensions of organizational commitment and Organizational Citizenship Behavior in various types of organizations. The research first confirmed the dependence of OCB on OC that has been reported by researchers $[20,53]$ investigating commitment as an antecedent of these behaviors. Secondly, they verified the assumption that these correlations exist in both public and private entities, which had not been researched on the Polish market earlier. Spearman's rank correlations in this case reached 0.489 and 0.527 , respectively. 
Looking at the dependence between the various dimensions of organizational commitment and $\mathrm{OCB}$, the results showed that it is most correlated with affective commitment. Spearman's correlations reached 0.702 in public institutions and 0.656 in private institutions. Therefore, a statistically significant positive relationship between organizational citizenship behavior and affective commitment in both types of organizations was demonstrated. Affective commitment means that an employee is emotionally connected with the organization. The employee feels that his/her goals and needs are being met. The employee receives support and therefore wants to support others. That is why an employee who is affectively engaged displays citizenship behavior the most. In this way he/she can feel fulfilled, identifies with the organization and helps others, and all this increases the efficiency of his/her workplace. Therefore, every organization, regardless of whether it is public or private, should strive to meet its employees' needs and goals. They will then be much more integrated with the organization, and thus the level of their affective commitment will be higher, which will then translate into a higher level of citizenship behavior. However, managers must take these actions already at the stage of strategic management when planning the vision, mission or goals of the organization.

Organizational citizenship behaviors are also positive, but less correlated with normative commitment. After all, this kind of commitment expresses a sense of duty and loyalty to the organization. Therefore, employees who display this dimension of commitment also feel the obligation to display citizenship behavior.

The same data analysis also showed that there are no correlations between continuance commitment and OCB. This kind of commitment is an expression of the compulsion to stay in the organization, often resulting from the cost calculation of leaving. Employees who are involved in their organization only because, for example, they do not see an alternative workplace, do not go beyond their formal duties.

\section{Conclusions}

\subsection{Conclusion and Theoretical Implication}

This article did not intend to analyze the organizational commitment of the respondents, which depends on many factors. Instead it was to confirm the assumptions that this commitment has a positive impact on the manifestation of organizational citizenship behavior regardless of the place of employment-actually, regardless of the type of organization in which employment is undertaken. Indeed, all the results confirmed this, as shown above. The increase in involvement leads to enhanced manifestations of citizenship behavior.

The study therefore confirmed previous studies such as Aslam et al. [73] and Ibrahim and Aslinda [74] in asserting a positive relationship between OCB and organizational commitment. Organizational commitment has consistently been found to be the most significant determinant of OCB. Mowday, Porter, and Steers [53] believe that engaged employees want to help the entire organization function better, and so are happy to do extra work. One will happily engage in various activities of benefit to the general public $[75,76]$. In addition, highly committed employees normally perceive their job duties to be more broad, which supposedly improves individuals' motivation to demonstrate OCB $[34,77,78]$. The research results presented in this article are also consistent with the studies of Michael Asiedu, Jacob Owusu Sarfo, and Daniel Adjei [79]. These authors examined the engagement of 200 bank employees and their citizenship behaviors. Their results clearly indicated a strong, statistically significant positive correlation between the two variables. This result was also supported in previous studies $[34,80]$

However, research results have emphasized that organizational citizenship behavior correlates positively with affective engagement. Conversely, there is no correlation between OCB and continuance commitment. Such a relationship has already been established in studies by, inter alia, Mayer and Schoorman [81], Chen, Hui and Sego [82], Riketta [83] and Meyer, Allen, and Topolnytsky [84]. These results are probably explained by the fact that entities with higher long-term engagement are expected to establish better exchange relationships within their organizations. Based on contract theory 
"individuals who consider their relationship with organization as primary instrumental are found to be more likely to prohibit their professional obligations to those activities which they are paid for i.e., intra-role behaviors. A relational contract, in contrast, encompasses advanced level of affectivity that facilitates workers to assume a much wider view of their relationships with organization and therefore promote extra-role behaviors" [85].

The results of this work also showed that the level of OCB in public and private institutions is similar. Employees of public entities, however, more often engage in citizenship behavior directed at colleagues than at the organization. It can be presumed that the less favorable working conditions (especially financial) in the public sector integrate employees more and strengthen their willingness to provide mutual assistance. Moreover, it must be emphasized that the private sector is constantly exposed to competition. Perhaps this explains why, as the research shows, organization-oriented OCBs are more significant in private institutions. Employees of these entities are aware that only outstanding organizations can survive in a competitive market, which will allow them to maintain their jobs. Therefore, managers of public organizations should focus on strengthening their employees' loyalty to the organization, while private sector managers should focus on building strong relationships and social ties between employees.

The present results are consistent with those presented in this area by other authors. For example, A. Glińska-Neweś and D. Szostek obtained a similar picture of OCB in the public and private sectors [4]. Meanwhile, E. Snape and T. Redman [86], when conducting research on human resource management practices and citizenship behavior in enterprises and public organizations, also noticed that employees of private organizations more often exhibit behaviors related directly to professional duties (role behavior), and in public ones they show greater altruism.

However, the most important implications for researchers here stem from the results that clearly show that the dependence of OCB on engagement occurs in every organization, regardless of type. In both public and private organizations, citizenship behavior correlates most strongly with affective engagement. However, on analysis, the results are very significant to future studies; despite the very high affective involvement that was observed in the respondents, their level of manifestation of OCB manifestation is not very high. It must therefore be presumed that organizational citizenship behavior is not determined solely by one antecedent. This issue must be looked at comprehensively. All factors that affect OCB manifestation among employees should be analyzed simultaneously. Not only organizational commitment should be studied, but also job satisfaction, perception of fairness and task variables and leadership behaviors.

\subsection{Practical Implications, Limitations and Future Research Directions}

The results of the study have revealed several important aspects that managers should pay attention to. One is to understand that an employee who is especially engaged affectively, and thus emotionally connected to the organization, can bring many benefits.

According to the results of the study, this engagement will have a positive impact on organizational citizenship behavior. As suggested by Organ [1], a high level of employee OCB improves the organization's performance and increases innovation. Management should therefore do all it can to increase employee engagement and ensure that such people remain within the organization. As Narteh [87] suggests, internal marketing elements such as training, communication and awards can increase employee involvement. Following other researchers $[88,89]$ the author proposes that managers increase employee engagement by conducting training that, by increasing employee knowledge or skills, will change their attitudes and increase motivation.

According to the theory of social exchange, greater emotional engagement is associated with greater social support in the workplace. Employees who feel supported by their organization feel the need to "pay it back" to the organization, and therefore want to identify with it $[11,90]$. Thus, the entire organization and every manager should support each employee. If the employee feels this support, 
he or she will become increasingly attached to the organization and will transfer more of its social resources to it, even in the form of citizenship behavior.

It should be noted that managers should approach the problem of organizational citizenship behavior comprehensively. Employee engagement alone is not enough, but it is certainly the place to start from. Employees must also have job satisfaction and a sense of fairness. How the leader behaves, with regard to employee support in particular, also plays a huge role here.

The results have also shown that the dimension of organizational citizenship behavior depends on the type of organization. Employees in public entities more often direct their citizenship behavior towards colleagues, while employees in private entities orient towards the organization in theirs. Therefore, managers of public organizations should focus on strengthening their employees' loyalty to the organization, while private sector managers should aim to build strong relationships and social ties between employees.

The current study also has several limitations and future suggestions. First of all, the author did not use random sampling. As a result, the research sample was dominated by women. Most of the respondents were employed in public and private schools (but not only), and this may have affected the results. Research on a more numerous and diverse sample is required to confirm the findings. Secondly, the quantitative research method enabled the author to grasp a broader context of OCB in the studied sectors, notably other factors determining the frequency of OCBs by employees of the two sectors. Third, this study was conducted only in Poland.

The results obtained in this work indicate that future studies would do well to investigate the correlations between all determinants of OCB. At the same time, examining organizational commitment, job satisfaction, perception of fairness, task variables and leadership behaviors in public and private organizations would provide a full picture of the dependencies. It would also be extremely interesting in the future to analyze the relationships between organizational commitment, organizational citizenship behavior and corporate social responsibility in the public and private sector.

Funding: This research received no external funding.

Acknowledgments: The author wishes to express her gratitude to Professor Agata Sudolska for her suggestions. The author is also grateful for supporting the paper with statutory research funding of The Faculty of Economic Sciences and Management Nicolaus Copernicus University in Torun.

Conflicts of Interest: The author declares no conflict of interest.

\section{References}

1. Organ, D.W. Organizational Citizenship Behavior: The Good Soldier Syndrome; D.C. Heath and Company: Lexington, MA, USA, 1988.

2. Appelbaum, S.; Bartolomucci, N.; Beaumier, E.; Boulanger, J.; Corrigan, R.; Dore, I.; Girard, C.; Serroni, C. Organizational Citizenship Behavior: A Case Study of Culture, Leadership and trust. Manag. Decis. 2004, 42, 13-40. [CrossRef]

3. Smith, C.A.; Organ, D.W.; Near, J.P. Organizational citizenship behavior: Its nature and antecedents. J. Appl. Psychol. 1983, 68, 655-663. [CrossRef]

4. Glińska-Neweś, A.; Szostek, D. Organizational Citizenship Behaviors in Public and Private Sector. Contemp. Manag. 2017, 17, 45-58. [CrossRef]

5. Organ, D.W.; Podsakoff, P.M.; MacKenzie, S.B. Organizational citizenship behavior: Its nature, antecedents, and consequences. Pers. Psychol. 2006, 59. [CrossRef]

6. Nezakati, H.; Asgari, O.; Karimi, F.; Kohzadi, V. Fostering Organizational Citizenship Behavior (OCB) Through Human Resource Empowerment (HRE). World J. Manag. 2010, 2, 47-64.

7. Miroński, J.; Czaplińska, I. Organizacyjne zachowania obywatelskie-istota, znaczenie i uwarunkowania. In Behawioralne Determinanty Rozwoju Przedsiębiorczości w Polsce; Kulawczuk, P., Poszewiecki, A., Eds.; Fundacja Rozwoju Uniwersytetu Gdańskiego: Gdańsk, Poland, 2010; pp. 332-346. 
8. Spector, P.E.; Che, X.X. Re-examining Citizenship: How the Control of Measurement Artifacts Affects Observed Relationship of Organizational Citizenship Behavior and Organizational Variables. Hum. Perform. 2014, 27. [CrossRef]

9. Moorman, R.H. Relationship between organizational justice and organizational citizenship behaviors: Do fairness perceptions influence employee citizenship? J. Appl. Psychol. 1991, 76, 845-855. [CrossRef]

10. Graham, J.W. An essay on organizational citizenship behavior. Employ. Respons. Rights J. 1991, 4, $249-270$. [CrossRef]

11. Eisenberger, R.R.; Hutchison, H.S.; Sowa, D. Perceived organizational support. J. Appl. Psychol. 1986, 71, 500-507. [CrossRef]

12. Iqbal, S.; Farid, T.; Ma, J.; Khattak, A.; Nurunnabi, M. The Impact of Authentic Leadership on Organizational Citizenship Behaviours and the Mediating Role of Corporate Social Responsibility in the Banking Sector of Pakistan. Sustainability 2018, 10, 2170. [CrossRef]

13. Meyer, J.P.; Allen, N.J. Commitment in the Workplace: Theory, Research, and Application; SAGE Publications: Thousand Oaks, California, USA, 1997.

14. Lambert, E.G. The impact of job characteristics on correctional staff members. Prison J. 2004, 84, $208-227$. [CrossRef]

15. Steers, R.M. Antecedents and outcomes of organizational commitment. Admin. Sci. Quart. 1997, $22,46-56$. [CrossRef]

16. Porter, L.W.; Steers, R.M.; Mowday, R.T.; Boulian, P.V. Organizational commitment, job satisfaction, and turnover among psychiatric technicians. J. Appl. Psychol. 1974, 59, 603-609. [CrossRef]

17. Johar, E.R.; Norzanah, N.M.; Hassan, R.; Musa, R. Examining the effect of motivation on the influence of human resource practices and normative commitment among smes in selangore. Asia-Pac. Manag. Account. J. 2019, 14, 179-199.

18. Khan, S.; Jehan, N.; Shaheen, S.; Ali, G. Effect of Burnout on Organizational Citizenship Behaviors: Mediating Role of Affective and Continuance Commitment. Abasyn J. Soc. Sci. 2018, 2, 1-13.

19. Robbins, S.P. Organizational Behaviour; Prentice-Hall: New York, NY, USA, 2001.

20. Podsakoff, P.M.; MacKenzie, S.B.; Paine, J.B.; Bachrach, D.G. Organizational citizenship behaviors: A critical review of the theoretical and empirical literature and suggestions for future research. J. Manag. 2000, 26, 513-563. [CrossRef]

21. Kark, R.; Waismel-Manor, R. Organizational Citizenship Behavior: What's Gender Got To Do With It? Organization 2005, 12, 889-917. [CrossRef]

22. Pare, G.; Tremblay, M. The Measurement and Antecedents of Turnover Intentions Among it Professionals; Scientific Series: Montreal, QC, Canada, 2000.

23. Lin, C.; Peng, T.K. From organizational citizenship behaviour to team performance: The mediation of group cohesion and collective efficacy. Manag. Organ. Rev. 2000, 6, 55-75. [CrossRef]

24. Wei, Y. The benefits of organizational citizenship behavior for job performance and the moderating role of human capital. Int. J. Bus. Manag. 2014, 9, 87-99. [CrossRef]

25. Toshikawa, T.; Hu, H.W. Organizational Citizenship Behaviors of Directors: An Integrated Framework of Director Role-Identity and Boardroom Structure. J. Bus. Ethics 2017, 143, 99-109. [CrossRef]

26. Podsakoff, P.M.; MacKenzie, S.B. Impact of Organizational Citizenship Behavior on Organizational Performance: A Review and Suggestions for Future Research. Hum. Perform. 1997, 10, 133-151. [CrossRef]

27. Rego, A.; Cunha, M.P.E. Organizational citizenship behaviors and effectiveness: An empirical study in two small insurance companies. Serv. Ind. J. 2008, 28, 541-554. [CrossRef]

28. Bhatti, M.H.; Ju, Y.; Akram, U.; Akram, Z.; Bhatti, M.H.; Bilal, M. Impact of Participative Leadership on Organizational Citizenship Behavior: Mediating Role of Trust and Moderating Role of Continuance Commitment: Evidence from the Pakistan Hotel Industry. Sustainability 2019, 11, 1170. [CrossRef]

29. LePine, J.A.; Erez, A.; Johnson, D.E. The Nature and Dimensionality of Organizational Citizenship Behavior: A Critical Review and Meta-analysis. J. Appl. Psychol. 2002, 87, 52-65. [CrossRef]

30. Graham, J.W. Organizational Citizenship Behavior: Construct Redefinition, Operationalization, and Validation; Loyola University Chicago: Chicago, IL, USA, 1989; Unpublished working paper.

31. Podsakoff, P.M.; MacKenzie, S.B.; Moorman, R.H.; Fetter, R. Transformational leader behaviors and their effects on followers' trust in leader, satisfaction, and organizational citizenship behaviors. Leadersh. Q. 1990, 1, 107-142. [CrossRef] 
32. Moorman, R.H.; Blakely, G.L. Individualism-Collectivism as an individual difference predictor of organizational citizenship behavior. J. Organ. Behav. 1995, 16, 127-142. [CrossRef]

33. George, J.M.; Jones, G.R. Organizational spontaneity in context. Hum. Perform. 1997, 10, 153-170. [CrossRef]

34. Williams, L.; Anderson, S. Job satisfaction and organizational commitment as predictors of organizational citizenship and in-role behaviors. J. Manag. 1991, 17, 601-617. [CrossRef]

35. Spitzmuller, M.; Van Dyne, L.; Ilies, R. Organizational citizenship behavior: A review and extension of its nomological network. In The SAGE Handbook of Organizational Behavior; Barling, J., Cooper, C.L., Eds.; SAGE Publications Ltd: Los Angeles, CA, USA, 2008; Volume 1, pp. 106-123.

36. Van Dyne, L.; Cummings, L.; Parks, J. Extra-role behaviors: In pursuit of construct and definitional clarity. Res. Organ. Behav. 1995, 17, 215-285.

37. Schmidt, J. Rola i uwarunkowania rozwoju organizacyjnych zachowań obywatelskich w organizacjach, na przykładzie polskich organizacji pozarządowych. Studia Oeconomica Posnaniensia 2014, 2, 27-51.

38. Podsakoff, P.M.; MacKenzie, S.B. Organizational Citizenship Behavior and Sales Unit Effectiveness. J. Mark. Res. 1994, 31, 351-363. [CrossRef]

39. MacKenzie, S.B.; Podsakoff, P.M.; Fetter, R. The Impact of Organizational Citizenship Behavior on Evaluations of Salesperson Performance. J. Mark. 1993, 57, 70-80. [CrossRef]

40. George, J.M.; Bettenhausen, K. Understanding Prosocial Behavior, Sales Performance and Turnover: A Group-level Analysis in a Service Context. J. Appl. Psychol. 1990, 75, 698-709. [CrossRef]

41. Waddock, S. Parallel universes: Companies, academics, and the progress of corporate citizenship. Bus. Soc. Rev. 2004, 109, 5-42. [CrossRef]

42. Lichtenstein, D.R.; Drumwright, M.E.; Braig, B.M. The effect of corporate social responsibility on customer donations to corporate-supported nonprofits. J. Mark. 2004, 68, 16-32. [CrossRef]

43. Sen, S.; Bhattacharya, C.B.; Korschun, D. The role of corporate social responsibility in strengthening multiple stakeholder relationships: A field experiment. J. Acad. Mark. Sci. 2006, 34, 158-166. [CrossRef]

44. Mueller, K.; Hattrup, K.; Spiess, S.O.; Lin-Hi, N. The effects of corporate social responsibility on employees' affective commitment: A cross-cultural investigation. J. Appl. Psychol. 2012, 97, 1186-1200. [CrossRef]

45. Azim, M.T. Corporate Social Responsibility and employee behavior: Mediating role of organizational commitment. Rev. Bus. Manag. 2016, 60, 207-225. [CrossRef]

46. Glavas, A. Corporate social responsibility and employee engagement: Enabling employees to employ more of their whole selves at work. Front. Psychol. 2016, 7, 1-10. [CrossRef]

47. Wang, W.; Fu, Y.; Qiu, H.; Moore, J.H.; Wang, Z. Corporate Social Responsibility and Employee Outcomes: A Moderated Mediation Model of Organizational Identification and Moral Identity. Front. Psychol. 2017, 8. [CrossRef]

48. Saks, A.M. Antecedents and consequences of employee engagement. J. Manag. Psychol. 2006, 21, 600-619. [CrossRef]

49. Albdour, A.A.; Altarawneh, I.I. Corporate social responsibility and employee engagement in Jordan. Int. J. Bus. Manag. 2012, 7, 89-105. [CrossRef]

50. Freeman, E. The Stakeholder Approach Revisited. Z. Wirtsch.-Und Unternehm. 2004, 5, 228-241. [CrossRef]

51. Li, Z.F.; Minor, D.; Wang, J.; Yu, C. A Learning Curve of the Market: Chasing Alpha of Socially Responsible Firms. J. Econ. Dyn. Control Forthcom. 2018, 1-36. [CrossRef]

52. Peyrat-Guillard, D.; Glińska-Neweś, A. Positive organizational potential, organizational commitment and organizational citizenship behavior: A French/ Polish comparison. J. Posit. Manag. 2010, 1, 47-64. [CrossRef]

53. Mowday, R.T.; Steers, R.M.; Porter, L.W. The measurement of organizational commitment. J. Vocat. Behav. 1979, 14, 224-247. [CrossRef]

54. Dominic, E.; Salim, M.H. A Study on the Role of Organizational Commitment and Perception towards Organizational Justice and Fairness in triggering Organizational Citizenship Behavior among B School Faculty Members in Kerala. Rajagiri Manag. J. 2018, 12, 21-40.

55. Wahn, J.C. Sex differences in the continuance component of organizational commitment. Group. Organ. Manag. 1998, 23, 256-266. [CrossRef]

56. Meyer, J.P.; Allen, N.J. A three-component conceptualization of organizational commitment. Hum. Resour. Manag. Rev. 1991, 1, 61-89. [CrossRef]

57. Bańka, A.; Hauziński, A. Struktura i własności psychometryczne Skali Przywiązania do Zawodu (SPZ). Czas. Psychol. 2013, 19, 327-343. [CrossRef] 
58. Al-Jabari, B.; Ghazzawi, I. Organizational commitment: A review of the conceptual and empirical literature and a research agenda. Int. Leadersh. J. 2019, 11, 78-119.

59. Singh, A.; Gupta, B. Job involvement, organizational commitment, professional commitment, and team commitment. Benchmarking Int. J. 2015, 22, 1192-1211. [CrossRef]

60. Mahal, P.K. HR practices as determinants of organizational commitment and employee retention. IUP J. Manag. Res. 2012, 11, 37-53.

61. Łaguna, M.; Mielniczuk, E.; Wuszt, E. Rola trzech wymiarów przywiązania do organizacji na różnych etapach procesu podejmowania szkoleń. Pol. Forum Psychol. 2015, 20, 47-61. [CrossRef]

62. Beck, K.; Wilson, C. Development of affective organizational commitment: A cross-sequential examination of change with tenure. J. Vocat. Behav. 2000, 56, 114-136. [CrossRef]

63. Faloye, D.O. Organizational commitment and turnover intentions: Evidence from Nigerian paramilitary organization. Int. J. Bus. Econ. Dev. 2014, 2, 23-34.

64. Abreu, M.C.S.; Cunha, M.C.; Rebouças, S.M.P. Effects of personal characteristics on organizational commitment: Evidence from Brazil's oil and gas industry. Int. J. Hum. Resour. Man. 2013, 24, 3831-3852. [CrossRef]

65. Allen, N.J.; Meyer, J.P. Affective, continuance, and normative commitment to the organization: An examination of construct validity. J. Vocat. Behav. 1996, 49, 252-276. [CrossRef]

66. Bańka, A. Psychologia organizacji. In Psychologia. Podręcznik Akademicki; Strelau, J., Ed.; GWP: Gdańsk, Poland, 2000.

67. Mathieu, J.E.; Zajac, D. A review and meta-analysis of the antecedents, correlates, and consequences of organizational commitment. Psychol. Bull. 1990, 108, 171-194. [CrossRef]

68. Luchak, A.A.; Gellatly, I.R. A comparison of linear and nonlinear relations between organizational commitment and work outcomes. J. Appl. Psychol. 2007, 92, 786-793. [CrossRef]

69. Spector, P.E.; Fox, S.; Penney, L.M.; Bruursema, K.; Goh, A.; Kessler, S. The dimensionality of counterproductivity: Are all counterproductive behaviors created equal? J. Vocat. Behav. 2006, 68, 446-460. [CrossRef]

70. Bańka, A.; Wołoska, A.; Bazińska, R. Polska wersja Meyera i Alen Skali Przywiązania do Organizacji. Czas. Psychol. 2002, 8, 65-74.

71. Towers Perrin-ISR. Engage Employees Help Boost the Bottom Line, 26 June 2006. Available online: https://www.onrec.com/news/news-archive/engaged-employees-help-boost-the-bottom-line (accessed on 13 November 2019).

72. Juchnowicz, M. Zaangażowanie Pracowników; Polskie Wydawnictwo Ekonomiczne: Warszawa, Poland, 2014.

73. Aslam, M.S.; Ahmad, F.; Anwar, S. Job Burnout and Organizational Citizenship Behaviors: Mediating Role of Affective Commitment. J. Basic. Appl. Sci. Res. 2012, 2, 8120-8129.

74. Ibrahim, A.K.; Alsinda, A. Relationship between Organization Commitment and Organization Citizenship Behavior at Government Owned Cooperation Companies. J. Public Adm. Gov. 2013, 3, 35. [CrossRef]

75. Kidwell, R.E.; Mossholder, K.W.; Bennett, N. Cohesiveness and organizational citizenship behavior: A multilevel analysis using work groups and individuals. J. Manag. 1997, 23, 775-793. [CrossRef]

76. Schnake, M. Organizational citizenship: A review, proposed model, and research agenda. Hum. Relat. 1991, 44, 735. [CrossRef]

77. Tepper, B.J.; Taylor, E.C. Relationships among Supervisors and Subordinates' Procedural Justice Perceptions and Organizational Citizenship Behaviors. Acad. Manag. J. 2003, 46, 97-105. [CrossRef]

78. Morrison, E.W. Role definitions and organizational citizenship behavior: The importance of the employee's perspective. Acad. Manag. J. 1994, 37, 1543-1567. [CrossRef]

79. Asiedu, M.; Sarfo, J.O.; Adjei, D. Organisational commitment and citizenship behavior: Tools to improve employee performance., An internal marketing approach. Eur. Sci. J. 2014, 10, 288-305. [CrossRef]

80. Bolon, D.S. Organizational citizenship behavior among hospital employees: A multidimensional-analysis involving job satisfaction and organizational commitment. Hosp. Health Serv. Adm. 1997, 42, 221-241.

81. Mayer, R.C.; Schoorman, F.D. Predicting participation and production outcomes through a twodimensional model of organizational commitment. Acad. Manag. J. 1992, 35, 671-684. [CrossRef]

82. Chen, X.P.; Hui, C.; Sego, D.J. The role of organizational citizenship behavior in turnover: Conceptualization and preliminary tests of key hypotheses. J. Appl. Psychol. 1998, 83, 922. [CrossRef] 
83. Riketta, M. Attitudinal organizational commitment and job performance: A meta analysis. J. Organ. Behav. 2002, 23, 257-266. [CrossRef]

84. Meyer, J.P.; Allen, N.J.; Topolnytsky, L. Commitment in a changing world of work. Can. Psychol. 1998, 39, 83-93. [CrossRef]

85. Jardat, R.; de Rozario, P. Psychological contracts in organizations: Understanding written and unwritten agreements. Soc. Bus. Rev. 1998, 43, 184-186. [CrossRef]

86. Snape, E.; Redman, T. HRM Practices, Organizational Citizenship Behaviour, and Performance: A Multi-level Analysis. J. Manag. Stud. 2010, 47, 1219-1247. [CrossRef]

87. Narteh, B. Internal marketing and employee commitment: Evidence from the Ghanaian banking industry. J. Financ. Serv. Mark. 2012, 17, 284-300. [CrossRef]

88. Liu, Z.; Li, J.; Zhu, H.; Cai, Z.; Wang, L. Chinese firms' sustainable development-The role of future orientation, environmental commitment, and employee training. Asia Pac. J. Manag. 2014, 31, 195-213. [CrossRef]

89. Verhulst, E.; Boks, C. Employee Empowerment for Sustainable Design. J. Corp. Citizen. 2014, 55, 73-101. Available online: https://www.jstor.org/stable/jcorpciti.55.73 (accessed on 12 November 2019). [CrossRef]

90. Eisenberger, R.; Armeli, S.; Rexwinkel, B.; Lynch, P.D.; Rhoades, L. Reciprocation of perceived organizational support. J. Appl. Psychol. 2001, 86, 42-51. [CrossRef]

(C) 2019 by the author. Licensee MDPI, Basel, Switzerland. This article is an open access article distributed under the terms and conditions of the Creative Commons Attribution (CC BY) license (http://creativecommons.org/licenses/by/4.0/). 